\title{
9. Community Development as Fantasy? A case study of contemporary Maori society
}

\author{
Toon van Meijl \\ University of Nijmegen
}

In 1999, Nicolas Peterson received the Lucy Mair Medal for Applied Anthropology from the Royal Anthropological Institute of Great Britain and Ireland, and in what follows I engage with his longstanding interest in the intersection between legal, political, economic and socio-cultural development issues amongst Indigenous communities in Oceania (see also Kubota and Martin, this volume). Since the 1970s, Nic Peterson has been involved in many land claims, and in more recent years he has also written numerous native title reports in support of Aboriginal communities aspiring to obtain land rights to their traditional territories. The research he has conducted for these claims and reports also raises anthropological issues - for example, regarding the sociocultural organisation of Aboriginal communities, especially the question of whether internal diversity can hamper legal and political successes (Peterson 1996).

This chapter follows the same trajectory, within the context of development rather than land rights. It explores the issue of internal diversity in light of its ramifications for development through reflecting on the concept of community as it has emerged in social anthropology and in development discourses, with a focus on the implications of different connotations of community for development practices. A central question has been why very few projects in community development can be labelled successful, not only in Oceania but around the world (for example, Escobar 1995; Gardner and Lewis 1996; Hobart 1993; Schuurman 1993). Using a Maori case study from New Zealand, I argue that 'community development' is usually based on a conception of community that bears little resemblance to the diverse and dynamic sociocultural contexts described in recent ethnography, and that this is a major factor in the failure of many community development projects. In order to provide some context for the analysis, I first note some key developments in the history of the term. 


\section{Revisiting the Concept of Community}

The word 'community' derives from the Latin communitas, which referred to a fellowship or a group sharing much in common. In the nineteenth century, the German sociologist Ferdinand Tönnies produced Gemeinschaft und Gesellschaft (1979), a work that contrasted 'Gemeinschaft' (usually translated as 'community') with 'Gesellschaft' (usually translated as 'society' or 'association'). Tönnies argued that Gemeinschaft represents a population integrated by a perfect unity of human wills ('vollkommenen Einheit menschlicher Willen'; Tönnies 1979: 7), whilst Gesellschaft is created by relations between individuals calculating their own self-interest. Gemeinschaft is created by shared kinship connections, beliefs and social experiences, whilst on entering Gesellschaft, one enters a 'strange country' ('Man geht in die Gesellschaft wie in die Fremde'; p. 3). This ideal typical distinction drew on Marx's theory of alienation and criticised rapid industrialisation and urbanisation, which supposedly undermined the traditional communitarian Gemeinschaft in the German countryside.

In the twentieth century, this concept of Gemeinschaft or 'community' would become important in sociology and social anthropology. Tönnies' typology directly influenced Durkheim, who generated a parallel contrast between mechanical and organic solidarity (Giddens 1971: 70-81). The assumption of close integration of social relations in pre-modern societies was also foundational to British structural functionalist anthropology, and was influential on American thinkers such as Talcott Parsons and Robert Redfield. Redfield renovated the concept of Gemeinschaft in The Little Community (1955), which described fieldwork in the Mexican villages of Tepoztlán and Chan Kom. The 'community' became a classic category and ethnographic field research took the 'village' or 'community' as the primary unit of study (Stasch 2009: 8). As it gained popularity, however, its imprecision became increasingly clear. George Hillery jr (1955) followed Kroeber and Kluckhohn's (1952) analysis of the term 'culture' and subjected 94 sociological definitions of the concept of community to qualitative and quantitative analysis. He identified 16 different definitional types of concepts within the sample and found only one concept that was common amongst the 94 definitions: they all dealt with people (Hillery 1955: 117). Nevertheless, the majority of studies contained other points of commonality; 69 of the 94 were in accord that a community should be understood as meaning a group of people who inhabit a common territory for at least some of the time, who share social interaction and who have one or more additional common ties (Hillery 1955: 118; see also Hillery 1959). 
Despite its inadequacies, and despite it being declared dead by some (Clark 1973), the term remains popular in a range of contexts and discourses. A component of this popularity is geographic; communities form a convenient way of spatially ordering human populations, not least for the purposes of research. Yet for the social science practitioner, patterns of social relationships usually extend beyond particular settlements and are not necessarily tied to specific geographic localities. Furthermore, the term is used not only in relation to smaller settlements, such as villages or towns, but perceptively also to describe social relations at the level of the nationstate (for example, Anderson 1983) - a scale well beyond that of the village. Indeed, sociologists have rejected the concept of community for empirical research on the basis of these methodological inconsistencies (Stacey 1969).

In anthropology, the term has not been abandoned, but contemporary anthropologists based in small-scale settlements generally make considerable efforts to represent such locations as diverse and interconnected rather than depicting them as homogenous and self-contained. Changes in anthropological conceptions of community parallel changing conceptions of culture, the meaning of which has shifted to include the diversity and derivations of a variety of constructions, representations and interpretations of culture by individuals and/or subgroups in a certain society (Kuper 1999). And this relatively new insight forces anthropologists to look beyond the communal sentiments in the communities in which they situate their studies.

In view of these criticisms and the associated ambivalence of the concept of community in the social sciences, it is paradoxical that in development discourses the term still evokes a range of positive connotations that echo the original formulations of Tönnies, Durkheim and Marx. In development discourses, a loss of 'community' is often lamented in the wake of the transition from rural to predominantly urban societies over the past century, and remaining rural locations become sites for appropriate 'community development' as an alternative to the choice between rural poverty and urban dislocation. In practice, however, the discrepancy between positive popular valuations of 'community' and academic critiques of the concept can lead to confusion, especially in the context of community development projects. Such projects still tend to be based on a putative form of homogeneity, but this assumption cannot adequately account for the struggles for political, cultural and symbolic capital that frequently hamper the organisation and success of development projects. In order to demonstrate this point, I will explore the practice of 'development' as it has occurred in a Maori 'community' over recent decades. 


\section{Constructing Maori Communities}

In contemporary Maori ideology, the word 'community' evokes a range of connotations that remind us of the original meaning presented by Tönnies: cohesion, integration, communality, solidarity, egalitarianism and homogeneity. The connotation of communality in the concept of community accords with the socio-political arrangement of Maori society, which is organised on the basis of whanaungatanga or 'relatedness' on the one hand, and rangatiratanga or 'chieftainship' on the other. Relatedness, in turn, is associated with the complementary emotions of aroha or 'love' and manaakitanga or 'caring and sharing', while the authority of so-called chiefs is transcended in kotahitanga or 'oneness'.

The term whanaunga refers primarily to relatives or blood relations, which are undoubtedly privileged above affines and non-relatives, but the meaning of whanaungatanga is nowadays often extended to include all Maori people in contradistinction to non-Maori-generally referred to as Pakeha (Metge 1995). Indeed, Maori people frequently establish rapid relations based on fictive kinship, so I too favour the concept of relatedness above kinship or consanguinity to describe Maori social organisation. This omnipresent feeling of relatedness is explained in a variety of different ways, with reference to cosmogony connecting all life through genealogies involving gods, ancestors and their descendants, the myth of the Great Fleet regarding the collective arrival of all Maori tribes in New Zealand after which they dispersed across the country, or more broadly to Maori indigeneity and a unique sense of belonging among them as the Indigenous people of Aotearoa New Zealand. In practice, Maori people generally refer to sharing social and cultural similarities, and these are rooted in an ideology of common descent and kinship.

Maori political organisation also emphasises the connections between chiefs and others, in spite of the relationship between them being similar to the hierarchical patterns of organisation that are so characteristic of Polynesian societies. Contrary to the autocratic societies elsewhere in Polynesia, the power of chiefs in Maori society is, however, far from absolute because their structural authority is inverted in an ideology of relatedness and reciprocity between chiefs and their tribes. Chiefs, in other words, are considered mainly as representatives of the people, as primus inter pares. This, and the fact that they must actualise the potentiality for power ascribed to them by birth, places limits on chiefly power.

Social and political organisation are both complemented by emotional concepts expressing the unity of Maori people. Thus, relatedness is often expressed in terms of aroha and the notion of 'caring and sharing' among all people of Maori descent, while the so-called complementarity between chief and people is 
generally expressed in terms of the need for chiefs to consult their people until consensus is reached. This discourse of love, caring and sharing, consultation and consensus confirms the association of communality and solidarity that the concept of community suggests, and on which many development projects rest.

The ideology of Maori egalitarianism outlined above was still attractive in the 1970s and 1980s because traditional forms of Maori hierarchy had subsided following the dispossession of the Maori in the nineteenth century, after which chiefs had very little economic power and only ceremonial power. The Maori renaissance that started in the late 1960s also reinforced feelings of harmony in Maori communities. Maori people were drawn together more intensively in response to the European domination in New Zealand. A common history of dispossession and marginalisation also caused people to construct a pre-colonial past in which the problems resulting from colonisation were still absent. In this imagined construction of the past, Maori community life was idealised as practically without problems, mainly because it served as a model for a sovereign Maori future. Indeed, distinctions between the past, present and future were, in analogy with Maori mythology and ceremonies, collapsed into a new transhistorical view of a Maori community. Time distinctions were irrelevant in the way in which local Maori talked about their community as a form of a timeless communitas, which in spite of European colonialism had proved strong enough to survive and that for the same reason could be revitalised in order to prepare Maori for a future in which they would themselves be in control again. Thus, a shared history caused Maori to feel close together and ready for the future. In my doctoral dissertation supervised by Nicolas Peterson, I demonstrated in some detail that the values associated with this revitalised sense of Maori community are articulated especially in inter-ethnic discourses in order to justify the need for tribal development programs and, ultimately, to regain Maori sovereignty (Van Meijl 1991).

In the practice of development projects, however, it became clear that Maori egalitarianism and the sense of community to which Maori frequently referred in the discourse of Maori traditions had been crosscut by the rise of a Maori middle class and, to a limited extent, upper class. Interestingly, Maori middle and upper classes partly overlapped with higher-ranking families in traditional Maori hierarchy, mainly because more members of chiefly families had been educated. Accordingly, emerging class differences also reinforced traditional patterns of hierarchy to the extent that development projects enabled chiefly families, especially members of chiefly families who were educated, to found their higher-ranking positions financially - for example, by becoming employed as project managers. Indeed, development brought to light that the community that was supposed to be relatively egalitarian and homogeneous was at the same time rather hierarchical. Development projects strengthened traditional 
hierarchy in Maori communities since higher-ranking individuals and family members were given the positions of responsibility and authority (Van Meijl 1997). Tribal settlements appeared to be tightly organised only in some sociocultural dimensions of village life, whereas they turned out to be deeply divided when funding arrived in the community's bank account and decisions had to be made about spending and management (see also Van Meijl 1991: 87-122). The process of reinforcing traditional hierarchy gathered further momentum when the New Zealand Government began redressing the land alienation of the nineteenth century by returning some land and additional compensation funds in the mid-1990s. Chiefs do have political influence as well as economic power now - at least much more than 25 years ago - so the sense of community that was (re-)constructed in the 1970s and 1980s has diminished.

\section{A History of 'Community Development'}

In the early 1980s, when I began my fieldwork in New Zealand, the struggle for recognition of the Treaty of Waitangi was still in its infancy, but it is important to point out that the developments described in this chapter parallel a national revival of Maori culture and the increasing politicisation of Maori aspirations throughout New Zealand (for example, Walker 2004). Initially, Maori demands for justice were phrased largely in terms of a discourse of development aimed at equity and equality between Maori and the descendants of immigrant settlers in New Zealand.

My access to a Maori community followed an invitation, through my Dutch supervisor, from a Maori leader with a degree in social anthropology, who had initiated a large-scale development strategy in his own tribal area. At the same time, he had invited a range of anthropologists into his home community to support his development projects and to become overseas 'ambassadors', as he phrased it, of Maori self-determination. Maori demands for political change date, of course, from the beginning of colonisation, but the political tide for recognition of Maori rights as Indigenous people began turning only from the late 1960s. Local developments began in the mid-1970s and in a broad sense they continue today.

In the North Island location where I did fieldwork, the strategy for 'development' was launched following the erection of a power station in the midst of a number of Maori settlements at Huntly in the early 1970s. The Huntly Power Station boosted the local economy to some extent, but it did not deliver employment for local Maori. They made up some 40 per cent of the town's population, but 
they were not sufficiently qualified for the new jobs. The power station also had a significant impact on the natural and socio-cultural environment, particularly because it sat next to Waahi $\mathrm{Pa}$ - a principal settlement of all regional tribes.

Waahi Pa is a Maori settlement of special significance that functions as a nexus for all Tainui tribes and beyond who are associated with the Maori King Movement or Kingitanga. Waahi Pa is the home of the 'paramount family' of the movement, led by the present Maori King Tuheitia, who succeeded his charismatic mother, Dame Te Atairangikaahu, in 2006. The Kingitanga was established in opposition to the imminent threat of colonial domination in the late 1850s (Van Meijl 1993a). At present, the movement is supported primarily by the Tainui tribes. Tainui is a loosely structured confederation of tribes whose ancestors reached the land of the 'long white cloud' (Aotearoa) on the same canoe from eastern Polynesia some 1000 years ago.

As home of the Maori monarchy, Waahi Pa is the main marae or ceremonial centre in Huntly. Waahi is a special marae not only because it is the centre of the Kingitanga, but also because, contrary to most other marae, a significant number of Maori people have settled on and around the marae site. Altogether approximately 350 people are living near Waahi. Although the Maori of Waahi $\mathrm{Pa}$ constitute the tangata whenua, the 'people of the land' of Huntly, they by no means represent the entire Maori population of the town. In this chapter, however, I am concerned primarily with the Maori community associated with the local marae, Waahi Pa, because it was they who generated a wave of development following the construction of the power station.

The local Maori population was particularly angry with the decision to construct the power station, as they were not consulted yet had to bear the greatest disruption because of their location. The Government's refusal to enter into separate negotiations with Maori people seemed to be based on a distinct lack of awareness that their needs were in any way different from the general Huntly population. This political naivety existed despite the fact that the power station would be erected right in the middle of the Maori community around Waahi Pa marae, requiring a number of Maori households to be removed from their land and relocated in Huntly Borough. Extended families and sub-tribal ramages were broken up and a large block of land was lost, which evoked memories of the land confiscations of the nineteenth century. The quality of life deteriorated in its social, cultural and economic dimensions, people became apprehensive of the future and lost confidence in the existing social order, and finally the entire confederation of Tainui tribes was disrupted because its leadership resided at Waahi Pa. In spite of these changes, however, it is important to emphasise that the Maori living in the area did not object to the establishment of the power project as such, only that its positioning seemed a symbolic representation of the continuing intrusion on the Maori way of life by government. 
In 1977, the Prime Minister eventually recognised some Maori organisations for the first time as representing local Maori communities when he stated that as statutory authorities they were eligible for a share of the development levy. Under New Zealand law, developers engaged in a project costing NZ\$100 million or more must contribute 0.5 per cent to a social fund to meet the consequential increased costs of servicing the area and establishing cultural and recreational amenities. Only after this announcement was made did negotiations gather momentum. Eventually, a compensation settlement of an estimated NZ\$1.2 million was agreed on for the power station. The meeting house on Waahi Pa marae was uplifted and renovated, while a new dining hall and lounge were constructed to the design of an architect, with the marae community providing voluntary labour. The savings created by using their own labour allowed the marae to build a number of pensioner flats. The Ministry of Energy reimbursed the marae NZ\$560 000 to cover the cost of refurbishing. An additional NZ\$350 000 was obtained by a bank overdraft to complete redevelopment (Mahuta and Egan 1981: 13).

Thus, there were several positive outcomes of the negotiations. Apart from the compensation received for any harmful effects as a result of the power station's siting, the Waahi marae community was also drawn closer together. Galvanised by their experiences, they realised that they had become more politically active and visible to the bureaucracy. It was Maori solidarity within the marae community in response to an external challenge that motivated the development planners to negotiate. Furthermore, Waahi marae responded to the challenge by designing a plan for their own future.

When redevelopment of Waahi Pa was completed, the community had begun to revalue the marae and all it stood for as a refuge for their distinct way of life. The communal-based organisation of the marae came to be appreciated once again and gradually a model for community development began to be formulated. A plan was designed to extend accommodation on the marae and increase facilities around it. In addition, it was planned to start horticulture on the blocks of land still held in communal ownership when existing European leases on them expired. In the long term, the leadership of the community also aspired to realise the Kingitanga dream of buying back as much as possible of the confiscated lands. Eventually, it was hoped, a revitalised Maori environment in which people could sustain a living might cause kindred who had migrated to urban areas in search of employment to return to their roots.

After the initial stage of development based on the compensation settlement was completed in the early 1980s, the second stage was scheduled in more detail (see also Mahuta and Egan 1981). It was planned to expand and innovate marae facilities to create the opportunity for more Maori to live together in a relatively autonomous environment within New Zealand society. The model of using 
marae as a vehicle for 'community development' came from The Tainui Report, a review of all of the Tanui tribes written by the local chief annex anthropologist and a development consultant (Mahuta and Egan 1983). This influential report proposed to initiate tribal development through corporate financial planning, investments, marketing and training. Education and training were seen as crucial components of the strategy to develop, because the research on which the report was based had indicated that 65 per cent of the Tainui population was under the age of twenty-five but most of them were locked into a vicious circle of underdevelopment: low educational achievement, lower skilled jobs, high unemployment rates, low income, deprived status, low self-esteem, poor health and high crime rates. To achieve socioeconomic change and to ensure the survival of a distinct 'culture', a comprehensive program of development was advocated. The ultimate object was to regain control of their resources in order to manage their own affairs.

Development planning commenced when The Tainui Report was released in 1983. It is beyond the scope of this chapter to elaborate on the various development projects in any detail, but they can be summarised as focusing on the creation of employment through commercial ventures as well as on education. In the mid1980s, the political climate under the Labour government led by David Lange was more conducive to changing the socioeconomic position of Maori in New Zealand society by sponsoring a range of initiatives, especially in education. Bilingual kindergartens were established to revive the Maori language. The local primary school near the marae in Huntly was among the first to become bilingual, while in the late 1990s a secondary school was added to this successful project. The marae also housed one of the first training programs for Maori school drop-outs (Van Meijl 1994). Furthermore, the marae managed to obtain funding for a preventative health program that would become a model used throughout the country (Van Meijl 1993b). In the area of employment, a number of initiatives were taken, ranging from commercial horticulture to the development of farmland, the establishment of a controlled-temperature farm that used the waste heat from the discharge water of the power station, the planning of a tourist lodge, the creation of new businesses and the expansion of existing ones in conjunction with job training programs. The training programs were subsidised with government funding.

All these projects exemplify the changes that Waahi Pa marae underwent after the construction of the Huntly Power Station. In the 1970s, Waahi was still a community like most other Maori communities in New Zealand. The marae facilities were no longer used as an extension to family homes, but only occasionally for ceremonial gatherings at life crises or to entertain guests of the Maori Queen. Twenty years later, however, Waahi was the most innovative marae in New Zealand. The initial development of Waahi following negotiations 
with government authorities about compensation for the construction of the power station induced the construction of a model for community development that, in turn, sparked a fundamental review of the social, political, economic and cultural goals of the entire Tainui confederation of tribes. The Waahi model was not only being expanded across the Tainui region, it also attracted interest from other tribes. This makes it interesting to evaluate the outcomes of the initiatives that were undertaken in the 1980s.

\section{Deteriorating Developments}

The harsh reality in 2010 is that all community development projects that were started in the 1980s have been discontinued in the community in which I conducted research. Local people have made considerable progress in the domains of education, training and health, but these developments continue to be sponsored by the Government, as New Zealand is currently attempting to settle Maori grievances about the country's colonial past. On the other hand, the commercial projects described above that were set up within local communities in the region have all failed. There is a range of reasons why these commercial development projects have fallen into disarray since the late 1980s.

Obviously, the compensation funds for the construction of the power station dried up after a few years, while the economic recession that hit New Zealand very badly in those years made it extraordinarily difficult for new business ventures to become profitable without additional subsidies. Thus, when the financial assistance from local or national government programs was discontinued because of the financial crisis, most local initiatives ended almost immediately. At the same time, the leadership of the community and the tribe as a whole became deeply involved in negotiations about a settlement over the confiscations of their land in 1864. This became possible only after a series of political changes took place in New Zealand in the course of the 1980s. The first major settlement of Maori land claims was signed with this particular tribe, the adherents of the King Movement, in 1995. Needless to say, this settlement has had a major impact on tribal development, but its consequences for local communities must not be overestimated (Van Meijl 2003).

The settlement of the confiscations that was signed in 1995 did entail a range of commercial ventures, but these are all situated at the super-tribal level and they are also managed by people who are educated, many of whom do not belong to the tribe. Tribal development after the settlement did generate employment, but in many communities it does not make a significant difference for most Maori, including the community in which it was all started in the 1970s. Numerous 
Maori development projects have succeeded over the years, but the majority of those are funded with compensation funds from the settlement, which means that most of them are beyond reach for most members of local communities.

Indeed, a major difference between the post-settlement developments that have taken place and the local initiatives that have all failed is the involvement of the community. Large post-settlement developments are operated purely on a commercial basis, which implies that their management is not infrequently outsourced, whereas the small-scale 'community' projects initiated in the 1980 s failed partly for economic reasons as outlined above, but partly also because of internal divisions. It goes without saying that the problem is not the involvement of local people per se, but the commercial ventures reinforced the slumbering hierarchy within communities, as Elisabeth Rata (2000) has also demonstrated. In the late 1970s and early 1980s, the community operated as a collective, but as soon as money was transferred into the community's bank account, discussions about spending emerged and undermined the success of several projects. Thus, it appears that the conception of community in Maori society that was underlying local development initiatives was purely ideological.

I am not arguing that Maori communities themselves are incoherent; on the contrary, at least in the settlement in which I did fieldwork, people had a long history of living together, sharing tight genealogical connections, extended resistance against colonialism, a rich cycle of ceremonies and also a vision of a future in which Maori would be in full control of their destiny again. Against this background, it cannot be surprising that local people rapidly conceptualised themselves as a collective, as a community, in opposing a huge power station in the centre of the settlement. Yet that collective solidarity in the face of an external threat could not be the basis for sustained development conceptualised as a socialist experiment involving all members of a community that was considered relatively egalitarian (Dasler 1982). As a consequence, it appeared that the sense of community that was brought forward in the negotiations about the compensation for the construction of the power station and the funding of related development projects was of only relative use.

\section{Conclusion}

The phrase 'community development' was invented by developmental agencies and non-governmental organisations (NGOs) in reference to communities, usually in non-Western societies, that can be classified as 'underdeveloped'. Their naive conception of harmony and homogeneity, and the generalisation thereof, in non-Western 'communities' is widely known (Hobart 1993), but the question of how a Maori community itself came to adopt the term in the 1970s and 1980s 
is still to be addressed. The answer is simple: the local chief had a degree in anthropology and was familiar with the development literature, including the Latin American dependencia theory. Inspired by the terms of that theory, he developed a goal to discontinue Maori dependency on the welfare state of New Zealand and to become independent again as a people. The notion of development was thus derived from an international discourse that had been constructed by development brokers in Latin America. This discourse functioned effectively to criticise the gap between the rich and the poor, between Pakeha and Maori, but it was founded on a conception of communities that in anthropology and sociology had been controversial since Hillery's inventory of the wide range of different meanings in 1955. Since then, the concept of community continues to be used, just like culture, although there is consensus in academia about its limited analytical value. The demise of community development in Maori society again testifies to that effect. Although the dream of a new future in which Maori would regain sovereignty reunited various ranks of Maori communities in their aim to tackle the contemporary predicament of Maori in New Zealand, the process of development itself painfully brought to light that Maori communities are far from harmonious or homogeneous.

\section{References}

Anderson, B. 1983. Imagined Communities: Reflections on the Origin and Spread of Nationalism. London: Verso.

Clark, D. B. 1973. The concept of community: a re-examination. Sociological Review 21 (3): 397-416.

Dasler, Y. 1982. Kingitanga: the new approach. Listener 11 December: 16-20.

Escobar, A. 1995. Encountering Development: The Making and Unmaking of the Third World. Princeton, NJ: Princeton University Press.

Gardner, K. and D. Lewis, 1996. Anthropology, Development and the Post-Modern Challenge. London: Pluto.

Giddens, A. 1971. Capitalism and Modern Social Theory: An Analysis of the Writings of Marx, Durkheim and Max Weber. Cambridge: Cambridge University Press.

Hillery, G. A. jr 1955. Definitions of community: areas of agreement. Rural Sociology 20 (2): 111-23.

Hillery, G. A. jr 1959. A critique of selected community concepts. Social Forces 37 (3): 237-42. 
Hobart, M. (ed.) 1993. An Anthropological Critique of Development: The Growth of Ignorance.London and New York: Routledge.

Kroeber, A. L. and C. Kluckhohn, 1952. Culture: A Critical Review of Concepts and Definitions. Papers of the Peabody Museum of American Archaeology and Ethnology Vol. 47, No. 1. Peabody Museum of American Archaeology and Ethnology, Harvard University, Cambridge, Mass.

Kuper, A. 1999. Culture: The Anthropologists' Account. Cambridge, Mass., and London: Harvard University Press.

Mahuta, R. T. and K. Egan, 1981. Waahi: A Case Study of Social and Economic Development in a New Zealand Maori Community. Occasional Paper No. 12, Centre for Maori Studies and Research, Hamilton, NZ.

Mahuta, R. T. and K. Egan, 1983. The Tainui Report: A Survey of Human and Natural Resources. Occasional Paper No. 19, Centre for Maori Studies and Research, Hamilton, NZ.

Metge, J. 1995. New Growth from Old: The Whaanau in the Modern World. Wellington: Victoria University Press.

Peterson, N. 1996. Organising the anthropological research for a native title claim. In P. Burke (ed.) The Skills of Native Title Practice, pp. 8-15. Canberra: Australian Institute of Aboriginal and Torres Strait Islander Studies.

Redfield, R. 1955. The Little Community. Chicago: Chicago University Press.

Rata, E. 2000. A Political Economy of Neotribal Capitalism. Lanham, Md: Lexington.

Schuurman, F. J. (ed.) 1993. Beyond the Impasse: New Directions in Development Theory. London, UK, and Atlantic Highlands, NJ: Zed.

Stacey, M. 1969. The myth of community studies. The British Journal of Sociology 20 (2): 134-47.

Stasch, R. 2009. Society of Others: Kinship and Mourning in a West Papuan Place. Berkeley: University of California Press.

Tönnies, F. 1979 [1887]. Gemeinschaft und Gesellschaft. Darmstadt, Germany: Wissenschaftliche Buchgesellschaft.

Van Meijl, T. 1991. Political Paradoxes and Timeless Traditions: Ideology and Development among the Tainui Maori, New Zealand. Nijmegen, the Netherlands: Centre for Pacific Studies. 
Van Meijl, T. 1993a. The Maori King Movement: unity and diversity in past and present. Bijdragen tot de taal-, land-en volkenkunde 149 (4): 673-89.

Van Meijl, T. 1993b. A Maori perspective on health and its politicization. Medical Anthropology 15: 283-97.

Van Meijl, T. 1994. Second chance education for Maori school 'dropouts': a casestudy of a community training centre in New Zealand. International Journal of Educational Development 14 (4): 371-84.

Van Meijl, T. 1997. The re-emergence of Maori chiefs: 'devolution' as a strategy to maintain tribal authority. In G. M. White and L. Lindstrom (eds), Chiefs Today: Traditional Pacific Leadership and the Postcolonial State, pp. 84-107. Stanford: Stanford University Press.

Van Meijl, T. 2003. Conflicts of redistribution in contemporary Maori society: leadership and the Tainui settlement. The Journal of the Polynesian Society 112 (3): 260-79.

Walker, R. 2004 [1990]. Ka Whaiwhai Tonu Matou: Struggle Without End. Auckland: Penguin. 